\begin{tabular}{c}
\hline KeMAS 16 (1) (2020) 130-137 \\
Jurnal Kesehatan Masyarakat
\end{tabular}

\title{
Care Support Education: Optimization Model of Communication Change Behavior in Female Sex Workers
}

\author{
Muhammad Azinar $^{1 \bowtie}$, Arulita Ika Fibriana ${ }^{1}$, Ratu Matahari ${ }^{2}$, Alfiana Ainun Nisa ${ }^{1}$ \\ ${ }^{1}$ Public Health Departement, Universitas Negeri Semarang, Indonesia \\ ${ }^{2}$ Public Health Departement, Universitas Ahmad Dahlan, Yogyakarta Indonesia
}

\begin{tabular}{l} 
Article Info \\
\hline Article History: \\
Submitted February 2020 \\
Accepted June 2020 \\
Published July 2020 \\
\hline Keywords: \\
Care Support \\
Education, behavioral \\
prevention, HIV / AIDS \\
\hline DOI \\
https://doi.org/10.15294/ \\
kemas.v16i1.24993
\end{tabular}

\begin{abstract}
Female Sex Workers (FSW) are a group of populations at high risk of transmitting HIV/ AIDS. In Indonesia, it is predicted that more than 50\% of FSW suffer from sexually transmitted diseases (STDs), as well as in the district of Batang, Central Java, the most cases of HIV/AIDS in FSW. The main causes are weak sexual negotiation skills and economic reasons. The model of behavior change is the main key in decreasing cases of HIV/AIDS transmission. The Care Support Education (CSE) model is an innovative community-based behavior change communication. This research is pre experimental research with one group pretest posttest design. The population is FSW in Batang district localization totaling 123 people. Samples were taken by purposive sampling of 57 people. Test the effect of applying the CSE model on behavior change was analyzed using the Mc Nemar test. Condom use in risky sexual behavior among FSWs was still low (15.8\%). Factors that influence it are knowledge, attitudes, perceptions of vulnerability, seriousness, benefits, negotiation capabilities and customer support. The application of the CSE model can significantly increase knowledge ( $\mathrm{p}$ value 0.00006 ), attitude (0.0001), condom negotiation skills (0.000001) and practise of using condoms (0.000005).
\end{abstract}

\section{Introduction}

Cases of HIV / AIDS in Indonesia is increasing year after year. The trend of new cases in the last three years has a significant increase. New cases of HIV in 2015 were 30,935 cases. This case increased in 2016 to 41,250 , and in 2017 it reached 48,300 cases. Likewise the new AIDS case, in the last three years in general has also increased. In 2015 AIDS cases numbered 9,215 cases, in 2016 it increased to 10,146 , and in 2017 it dropped to 9,280 cases (Dirjen P2P, Kemenkes, 2018).

While in Central Java, HIV/AIDS cases in the last three years also experienced a significant increase. Cumulatively from 1993 to June 2018 in Central Java there have been 23,603 cases, 1,672 of whom died from this disease. This fact has made Central Java province ranked fifth in the highest number of HIV / AIDS cases nationally (Dirjen P2P, Kemenkes, 2018).

Batang Regency is one of the regions that has a large risk factor for HIV / AIDS transmission because it has the most localization sites in Central Java, which is 12 prostitution localizations spread along the northern coast of Java. Batang District AIDS Commission, said the cases in Batang continue to increase. Since 2007 to June 2018 there had been 1,039 cases of HIV / AIDS, 165 of them had died (Komisi Penanggulangan AIDS, 2018).

In the past year, 75 new cases of HIV / AIDS had occurred in the Batang district and 10 people had died. HIV / AIDS cases are dominated by women (63\%) and occur mostly 
in female sex workers (FSW). FSW considered as the group having the biggest risk factors for contracting and transmitting sexually transmitted diseases (STDs) including HIV / AIDS due to risky sexual behavior namely changes partners and does not use condom (Komisi Penanggulangan AIDS, 2018). This fact shows that HIV / AIDS is apprehensively increasing both in quantitative and qualitative terms especially at risk populations (FSW, customers and other risk communities in localization).

In Indonesia, it is predicted that more than $50 \%$ of FSW suffer STDs. This is exacerbated by the behavior of female sex workers who do not pay attention to their own health. Most FSW do not conduct health checks and seek information related to their health status due to economic reasons and their negative stigma. They prefer to buy their own medicines, including using antibiotics without medical consulting (Baral, 2012). The government and non-governmental organizations have made various efforts to reduce and prevent cases of HIV / AIDS transmission in high-risk populations, but these efforts have not been effective.

Poor knowledge of FSW related to HIV / AIDS, weak negotiation skills and reasons for earning more income are the main causes of the weak efforts to prevent HIV/AIDS transmission in localization (Exavery et al, 2012). FSW has borne a high burden of HIV infection in and throughout the HIV epidemic. Comprehensive community empowerment based HIV prevention interventions that emphasize sex worker organizations and mobilization to address HIV risk are essential (Wirtz et al, 2014).

Identification of risk factors for HIV / AIDS transmission among FSWs as highrisk populations is very important in order to be able to conduct behavioral change interventions through the development of effective and innovative models of education and health promotion in the prevention of HIV / AIDS transmission, especially in highrisk populations that are localized (Glanz et al, 2008). This study will analyze the application of the Care Support Education (CSE) model as a communication model and its effect on changes in FSW behavior in Batang District.

\section{Method}

This is a pre experimental research with one group pretest posttest design using a quantitative approach. The population is FSW in the Penundan location in Batang, which is 123 people. Samples were taken by purposive sampling, which has been residing in the localization for at least 2 months, is willing to attend the CSE program for 3 months and can read and write. Based on these requirements a sample of 57 people was obtained. This research protocol was reviewed and approved by the Health Research Ethics Commission (komisi etik penelitian kesehatan/KEPK), Semarang State University with Ethical Clearance number: 137 / KEPK / EC / 2019.

An overview of the CSE model implemented in this study: 1) CSE is an educational model developed based on the community (involving community members both as participants and as trained peersupport); 2) CSE aims to provide positive information and support to at-risk populations to implement HIV / AIDS transmission prevention behaviors; 3) CSE education model is $3 \mathrm{~F}$ (focus, friendly, and fun), i.e. Focus is divided into small groups of up to 10 participants with a peer-support. Friendly, namely the trust between peer-support and participants. Fun means that CSE is not formal education, but prioritizes openness, cheerfulness, comfort, relax, interspersed with motivational games and a more flexible atmosphere of the place; 4) CSE is held every 2 weeks for 3 months; 5) The focus of CSE targets includes: the facts of STDs and HIV/AIDS and their prevention and control in high-risk populations, awareness and motivation of the importance of using condom in risky sexual behavior, and training of alternative skills.

Application of Care Support Education (CSE) model as a communication model for changing behavior in the prevention of HIV / AIDS transmission among FSWs in limited groups, with the following description and intervention procedures: 1) establishing FSWs in small groups, 2) choosing FSW to be PeerSupports, 3 ) Peer-Support training, and 4) application of CSE models to FSW small groups that have been formed. Data analysis 
was performed with the Chi Square test to determine the determinants of HIV / AIDS transmission prevention behavior in FSW and Mc Nemar test to analyze the effect of the application of the CSE model on changes in FSW behavior.

\section{Result and Discussion}

Based on the results of the study, of the 57 FSWs participating in the Care Support Education (CSE) program, it was found that their average age was 29 years, the youngest FSW was 20 years old and the oldest was 47 years. The following data illustrates marital status, education level, length of service as sex workers, the practice of using condom in risky sexual activities among them.

At the beginning of this study, it was found that the use of condom in sexual behavior among FSWs was still very low (15.8\%). This means that there are still many sexual activities carried out by female sex workers and their customers without consistent condom usage. This has the potential to transmit sexually transmitted diseases (STDs), including AIDS.

The low use of condom in sexual behavior among FSWs is due to the lack of condom negotiation skills carried out to its customers. Economic reasons are also a factor contributes to the low use of condom in FSW (Baral, 2012). The following are determinants or factors that influence condom use behavior in sexual behavior among FSWs in localization.

Table 2 shows that 29 FSWs (50.9\%) had lacked knowledge about STIs and HIV/AIDS, 26 FSW (45.6\%) had a less supportive attitude towards preventing transmission of HIV/AIDS, 44 FSW $(77.2 \%)$ were less aware that they are a vulnerable group (high risk) that is infected and transmits HIV/AIDS, 43 FSW (75.4\%) were less aware that AIDS is a serious and deadly disease and 39 FSW (68.4\%) were also less aware of the benefits of preventing HIV transmission / AIDS in risk groups like them. Whereas judging from the ability to negotiate condom usage with their customers, 44 FSW (77.2\%) are less skilled in conducting condom negotiations.

Meanwhile, from the support given by its customers it is also still low. This is indicated by 38 FSW (66.7\%) stating that they had lack of support from their customers or it means that the customer does not want to use condom when engaging in sexual activity with FSW.

The results of correlation analysis with the chi square test showed that the factors

Table 1. Characteristic and behavior of FSW in localization in HIV/AIDS infection prevention

\begin{tabular}{lll}
\hline Variable & Frequence & $\%$ \\
\hline Marital Status & 4 & 7,0 \\
Single & 11 & 19,3 \\
Married & 42 & 73,7 \\
Widow/Divorced & & \\
Education Level & 2 & 3,5 \\
Not graduate from Elementary & 35 & 61,4 \\
Elementary graduate & 18 & 31,6 \\
Junior High graduate & 2 & 3,5 \\
Senior High Graduate & & \\
Work period as FSW & 13 & 22,8 \\
$<1$ year & 38 & 66,7 \\
1-5 years & 4 & 7,0 \\
years & 2 & 3,5 \\
$>10$ years & & \\
Using condom in risky sexual activity & 48 & 84,2 \\
Not always & 9 & 15,8 \\
Always & &
\end{tabular}

Source: Primary Data, 2019 
Table 2. Relation between knowledge, attitude, susceptibility perception, seriousness perception, benefit perception, negotiation skill and customer support with condom usage practice on FSW sexual behavior

\begin{tabular}{|c|c|c|c|}
\hline \multirow{2}{*}{ Variable } & \multicolumn{2}{|c|}{ CondomUsage } & \multirow{2}{*}{$P$ Value } \\
\hline & Not Always & Always & \\
\hline \multicolumn{4}{|l|}{ Knowledge } \\
\hline Poor & $28(96,6 \%)$ & $1(3,4 \%)$ & 0,012 \\
\hline Good & $20(71,4 \%)$ & $8(28,6 \%)$ & \\
\hline \multicolumn{4}{|l|}{ Attitude } \\
\hline Less supportive & $25(96,2 \%)$ & $1(3,8 \%)$ & 0,031 \\
\hline Supportive & $23(74,2 \%)$ & $8(25,8 \%)$ & \\
\hline \multicolumn{4}{|c|}{ Susceptibility Perception } \\
\hline Poor & $41(93,2 \%)$ & $3(6,8 \%)$ & 0,003 \\
\hline Good & $7(53,8$ & $6(46,2 \%)$ & \\
\hline \multicolumn{4}{|c|}{ Seriousness Perception } \\
\hline Poor & $39(90,7 \%)$ & $4(9,3 \%)$ & 0,032 \\
\hline Good & $9(64,3 \%)$ & $5(35,7 \%)$ & \\
\hline \multicolumn{4}{|c|}{ Benefit Perception } \\
\hline Poor & $36(92,3 \%)$ & $3(7,7 \%)$ & 0,022 \\
\hline Good & $12(66,7 \%)$ & $6(33,3 \%)$ & \\
\hline \multicolumn{4}{|l|}{ Negotiation Skill } \\
\hline Less skilled & $41(93,2 \%)$ & $3(6,8 \%)$ & 0,003 \\
\hline Skilled & $7(53,8 \%)$ & $6(46,2 \%)$ & \\
\hline \multicolumn{4}{|c|}{ Customer Support } \\
\hline Poor & $36(94,7 \%)$ & $2(5,3 \%)$ & 0,004 \\
\hline Good & $12(63,2 \%)$ & $7(36,8 \%)$ & \\
\hline
\end{tabular}

Source: Primary Data, 2019

that influenced the practice of condom usage in FSW sexual behavior were knowledge (0.012), attitude (0.031), susceptility perception (0.003), seriousness perception (0.032), benefit perception (0.022), FSW negotiation skills (0.003) and customer support (0.004).

The results are in accordance with Liying Zhang et al (2015), which states that self-efficacy, and perceptions of obstacles become predictions of the intention and behavior of condom usage consistency at FSW. Other research states that FSW is a high-risk population that is infected and transmits HIV/AIDS due to unsafe sexual behavior. Prevention of transmission is very important to be done by FSW, one of which is by adhering to the use of condom in risky sexual behavior. Non-compliance to condom usage is caused by FSWs not daring to refuse unprotected sexual relations (Kate et al. 2010). Consistent usage of condom is an effective strategy in the prevention of sexually transmitted infections and transmission of HIV/AIDS (Rotrease, 2013). Condom today are still a versatile prevention technology that can prevent unwanted pregnancy and sexually transmitted infections including HIV. If used correctly and consistently, condom can provide an optimal level of protection (Beksinska et al, 2019).

This is also consistent with the Health Belief Model theory that perceived susceptibility is a person's subjective perception of the risk of certain diseases. Someone will act to treat or prevent disease, if they feel vulnerable to the attack of the disease (Sarwono, 2007). This is one of the strong perceptions to encourage individuals to behave healthily. The greater the risk perception, the greater the likelihood of interest in healthy habits to reduce the risk that will occur. Perception of susceptible make someone feels confidence/believe in the possibility of sickness occured in him self. 
Table 3. The improvement of knowledge, attitude, negotiation skill, and condom usage practice before and after the implementation of Care Support Education (CSE) to FSW

\begin{tabular}{|c|c|c|c|}
\hline \multirow{2}{*}{ Variable } & \multicolumn{2}{|c|}{ Knowledge (Post-test) } & \multirow{2}{*}{ P Value } \\
\hline & Poor & Good & \\
\hline \multicolumn{4}{|c|}{ Knowledge (Pre-test) } \\
\hline Poor & $14(24,6 \%)$ & $15(26,3 \%)$ & 0,00006 \\
\hline \multirow[t]{3}{*}{ Good } & $0(0,0 \%)$ & $28(49,1 \%)$ & \\
\hline & \multicolumn{2}{|c|}{ Attitude (Post-test) } & \\
\hline & Less Supportive & Supportive & \\
\hline \multicolumn{4}{|c|}{ Attitude (Pre-test) } \\
\hline Less Supportive & $12(21,1 \%)$ & $14(24,6 \%)$ & 0,0001 \\
\hline \multirow[t]{3}{*}{ Supportive } & $0(0,0 \%)$ & $31(54,4 \%)$ & \\
\hline & \multicolumn{2}{|c|}{ Negotiation Skill (Post-test) } & \\
\hline & Less Skilled & Skilled & \\
\hline \multicolumn{4}{|c|}{ Negotiation Skill (Pre-test) } \\
\hline Less Skilled & $19(33,3 \%)$ & $25(43,9 \%)$ & 0,000001 \\
\hline \multirow[t]{3}{*}{ Skilled } & $0(0,0 \%)$ & $13(22,8 \%)$ & \\
\hline & \multicolumn{2}{|c|}{ Condom Usage Practise (Post-test) } & \\
\hline & Poor & Good & \\
\hline \multicolumn{4}{|c|}{ Condom Usage Practise (Pre-test) } \\
\hline Not always & $17(29,8 \%)$ & $31(54,4 \%)$ & 0,000005 \\
\hline Always & $0(0,0 \%)$ & $9(15,8 \%)$ & \\
\hline
\end{tabular}

Source: Primary Data, 2019

A person's actions to seek treatment or prevention are also encouraged because of the threat or seriousness of the disease. In addition, the perception of the benefits or benefits of acting will also affect an individual's belief in healthy behavior. Likewise, perceived obstacles can become obstacles in carrying out the recommended behavior (Sarwono, 2007). This perception refers to an individual's evaluation of barriers to behavior or healthy habits. Perceived Barriers are a significant factor in changing habits. When people or the community believe that new healthy habits or behaviors are more beneficial than old habits in reducing risk, new healthy habits / behaviors will be used.

Research by Greig, et al (2003), stated that women's negotiation and economic independence are the most powerful factors affecting their behavior in HIV / AIDS prevention, especially in the use of condom. This fact is consistent with the study of Lianne, et al (2012), which stated that internal factors, physical environment, economy, policy and social factors, are significantly related to HIV / AIDS prevention efforts through condom negotiations by FSW. The helplessness of sex workers is an obstacle to negotiating safe sex practices (Kate, et al, 2010). Another study by Exvery, et al (2012), which stated that the belief in negotiating the use of condom is a significant predictor in the practice of condom use.

In general, the results of the study have confirmed the Health Belief Model (HBM) theory. In the HBM concept it is stated that health behavior is determined by personal beliefs or perceptions about the disease and strategies available to reduce the occurrence of the disease (Glanz, et al, 2008)

The result of Care Support Education (CSE) model application shows that after attending the CSE program for 3 months, the results obtained was there is a significant increase in knowledge. FSW who before joining the CSE program had less knowledge, after participating in the CSE program, had knowledge improvement up to 43 people (75.4\%). According to the Mc Nemar test showed a $p$ value of $0.00006(<0.05)$, this shows a significant increase in the knowledge of FSW, before and after the FSW joined the CSE 
program. The following table shows differences in knowledge, attitudes, negotiation skills and practice of using condom.

Likewise, with the FSW attitude. After participating in the Care Support Education (CSE) program, FSW whose attitudes began to change realized (supporting) the importance of preventing HIV/AIDS transmission increased to 45 people $(79.0 \%)$ from before there was a CSE program of only 31 (54.4\%) with p value 0,0001 . Negotiation skills have also improved. The number of FSWs who were already skilled in negotiations before participating in the Care Support Education (CSE) program was $13(22.8 \%)$ increasing to $38(66.7 \%)$ after intensively participated in the CSE program.

The usage of condom among FSW has also increased. Before joining the Care Support Education (CSE) program, it was 9 persons (15.8\%), this number increased to 40 FSWs (70.2\%). The same thing with adherence to screening for STIs once a month also increased. Before participating in the CSE program, only 16 FSW (28.1\%) stated that they routinely attend IMS screening every month, after CSE program the number increased to 29 (50.9\%). The participation rates in VCT have also increased. FSW which stated that they routinely conducted VCT every 3 months were 15 FSW (26.4\%) increasing to $26 \mathrm{FSW}$ (45.7\%).

Care Support Education (CSE) developed in this research is a communication model for changing behavior in the prevention of HIV/ AIDS transmission in FSWs according to the problem and support for policies and rules that apply to localization. Through a behavioral change communication approach that is carried out in FSW peers in localization, this CSE model has been able to increase knowledge among groups, provide awareness and motivation on the importance of using condom in risky sexual behavior, as well as routine health checks, including STI screening and VCT. The results of this research are in line with Dewi (2008), which stated that health education provided to the Commercial Sex Workers (CSWs) community has an effect on the knowledge increase and attitudes of CSWs. Another study by Purnomo (2013), stated health education affects the increasing knowledge and attitudes in controlling HIV/AIDS.
The existence of mutual support or mutual giving to realize the importance of efforts to prevent transmission of HIV/AIDS among fellow FSWs has influenced the better awareness in preventing HIV/AIDS transmission by increasing condom usage, participation in STI screening and VCT. The results of this research are in accordance with Bateganya et al (2015) which stated group support can improve the perception of the benefits of prevention and the impact of ongoing HIV transmission. Peerbased prevention and treatment significantly reduce the incidence of HIV among young FSWs in Burkina Faso, through reducing risk behavior (Traore et al, 2015). These results are also consistent with the results of Purnomo's research (2013), which stated there is an influence of health education on increasing attitudes and awareness in controlling HIV/ AIDS,

The Care Support Education (CSE) can also improve FSW skill in condom negotiations through training and simulation of persuasion communication to its customers. They need to be empowered to not only refuse unprotected sex, but also to be able to motivate clients to use condom. Condom intervention and promotion must also be able to overcome the factors that affect the ability of FSW to negotiate condom usage (Bharat, et al, 2013).

The reason customers and FSWs are not willing to use condom is the lack of information about the importance of it as a prevention of transmission of sexually transmitted diseases including HIV/AIDS, the usage of condom is felt disturbing, uncomfortable, and can reduce pleasure.

The results are in line with Budiono's research (2012), which stated that factors proven to be related to condom usage practices are FSW knowledge about STIs and HIV/AIDS, FSW attitudes towards condom use, and access to information about STIs and HIV/AIDS. This result is also in line with Azam, et al (2014), the Community Educator integration model and the reward-punishment system, can improve the practice of condom usage among female sex workers (FSW).

\section{Conclussion}

The use of condom in sexual behavior among FSWs is still low (15.8\%), not all localized 
FSWs always attend IMS screening every month (71.9\%), and there are still many who do not always do VCT every three months (73,3\%). Factors that affect the practice of condom age in FSW sexual behavior are knowledge, attitudes, perceptions of susceptibility, perceptions of seriousness, perceptions of benefits, negotiation skill of FSW and customer support. Factors that affect compliance in conducting STI screening every month are knowledge, attitudes, perceptions of susceptibility, perceptions of seriousness, perceptions of benefits, and pimps' support. While the factors that affect compliance with conducting VCT every three months are knowledge, attitudes, perceptions of susceptibility, perceptions of seriousness, perceptions of benefits, and pimps' support.

The application of the Care Support Education (CSE) model has been able to improve knowledge, attitudes, condom negotiation skills, condom usage practise, FSW participation in STI screening, and FSW participation in VCT.

\section{References}

Azam, M., Fibriana, A. I., \& Azinar, M. (2014), Model Integrasi Pendidik Komunitas dan Sistem Poin "RP" (Reward-Punishment) untuk Pencapaian Condom Use 100\% di Lokalisasi. Jurnal Kesehatan Masyarakat, 25 32.

Baral, S. (2012). High and disproportionate burden of HIV among female sex workers in lowand middle-income countries: a systematic review and meta-analysis. 19th International AIDS Conference.

Bateganya, M., Amanyeiwe, U., Roxo, U., Dong, M. (2015). The Impact of Support Groups for People Living with HIV on Clinical Outcomes: a systematic review of the literature. J Acquir Immune Defic Syndr. 68(03), 368-374.

Beksinska, M., Wong, R., \& Smit, J. (2019). Male and female condoms: Their key role in pregnancy and STI/HIV prevention. J.bpobgyn 12(1).

Bharat, S., \& et al. (2013). Are female sex workers able to negotiate condom use with male clients? The case of mobile FSWs in four high HIV prevalence states of India. PLoS ONE 8(6).

Budiono, I. (2012). Konsistensi Penggunaan Kondom oleh Wanita Pekerja Seks/ Pelanggannya. Jurnal Kesehatan Masyarakat 7(2), 97-101.
Dewi, N. (2008). Pengaruh Pendidikan Kesehatan terhadap Perubahan Pengetahuan dan Sikap dalam Pencegahan HIV dan AIDS pada Pekarja Seks Komersial. Media Ners. 2(1), $1-44$.

Dirjen P2P Kemenkes. (2018). Statistik Kasus HIV/ AIDS di Indonesia Trimester IV Tahun 2018. Jakarta: Kemenkes RI.

Exavery, A., \& et al. (2012). Role of condom negotiation on condom use among women of reproductive age in three districts in Tanzania. BMC Public Health, 12:1097.

Glanz, K., Rimer, B., \& Viswanath, K. (2008). Health Behavior and Health Education Theory, Research and Practise. Jossey Bass.

Greig, F., \& Koopman, C. (2003). Multilevel analysis of women's empowerment and HIV prevention: Quantitative survey results from a preliminary study in Botswana. AIDS Behaviour. 7, 195-208.

Purnomo, K.I., M, Bhisma., \& Putu, S. (2013). Perbandingan Pengaruh Metode Pendidikan Sebaya Dan Metode Ceramah Terhadap Pengetahuan Dan Sikap Pengendalian HIV/ AIDS Pada Mahasiswa Fakultas Olahraga Dan Kesehatan. Jurnal Magister Kedokteran Keluarga Universitas Pendidikan Ganesha, 1(1), 49-56.

Komisi Penanggulangan AIDS. (2018). Kondisi HIV/AIDS di Kabupaten Batang tahun 2018. Batang: Komisi Penanggulangan AIDS Kabupaten Batang.

Rotrease, R. (2013). Perceptions About HIV and Condoms and Consistent Condom Use Among Male Clients of Commercial Sex Workers in the Philippines. Health Education \& Behavior, 40 (2).

Sarwono, S. (2007). Sosiologi Kesehatan. Yogyakarta: Gajah Mada University Press.

Kate, S., \& Csete, J. (2010). Violence, Condom Negotiation, and HIV/STI Risk Among Sex Workers. JAMA: The Journal of American Medical Asotiation, 304(5), 573-574.

Lianne, A., Urada., \& et al. (2012). Condom Negotiations among Female Sex Workers in the Philippines: Environmental Influences. PloS ONE. 7 (Issue 3).

Traore, T., Isidore \& et al. (2015). HIV prevention and care services for female sex workers: efficacy of a targeted community-based intervention in Burkina Faso. J Int AIDS Soc 18(1).

Wirtz, A., \& et al. (2014). Epidemic Impacts of a Community Empowerment Intervention for HIV Prevention among Female Sex Workers in Generalized and Concentrated Epidemics. 
PLoS ONE. 9(2).

Zhang, L., \& et al. (2015). Predictors of Consistent Condom Use Among Chinese Female Sex
Workers: An Application of the Protection Motivation Theory. Health Care Women Int 36(7), 816-833. 